\title{
Simulation model for bull:cow ratio in beef cattle
}

\section{Modelo de simulação para a relação touro: vaca em bovinos de corte}

\author{
Valdir Trindade Filipini ${ }^{1}$, José Victor Vieira Isola ${ }^{2}$, Adriana Pires Neves ${ }^{1}$, Marlon Risso Barbosa ${ }^{3}$, \\ Barbara Cristina dos Santos Wienke ${ }^{4}$, Natálie Pontes Scherer ${ }^{1}$, José Acélio Silveira da Fontoura Júnior ${ }^{1}$ \\ ${ }^{1}$ Universidade Federal do Pampa, Curso de Zootecnia, Campus Dom Pedrito, Dom Pedrito - RS, Brazil \\ ${ }^{2}$ Universidade Federal de Pelotas, Faculdade de Veterinária, Departamento de Veterinária, Pelotas - RS, Brazil \\ ${ }^{3}$ Universidad de la Republica del Uruguay, Facultad de Veterinária, Montevidéo, Departamento de Montevidéo, Uruguay \\ ${ }^{4}$ Sindicato Rural de São Lourenço do Sul, Departamento de Zootecnia, São Lourenço do Sul - RS, Brazil
}

\begin{abstract}
The most used reproduction method in beef cattle in Brazil is natural breeding, which corresponds to $84 \%$ of calves born. Breeders adopt the bull:cow ratio of 1:25, which results in a sub utilization of bulls, making natural breeding antieconomic and underestimating the reproductive ability of competent bulls. The bull:cow ratio is determined by several factors, such as climate and nutrition, but the most determining factor is the fertility of the bull, estimated with more precision through breeding soundness examination of bulls. The aim of this study was to develop a simulation model as an aid to choose the best bull:cow ratio according to the combination of the many factors that determine this ratio. It is a conceptual, empiric, static, and determinist model which, through the processing of the input data, simulates the best BCR. Developed on the Vensim PLE 6.1 software, the model describes variables related to bulls and cows. Two equations were generated to predict the mating potential of males. In the same way, according to the reproductive status of females, equations were generated to predict the cyclicity rate of the cows. The sum of these equations originated the one that determines BCR according to the reproductive status of females. This model might serve as a tool to support decisions as to the best BCR and could be used with several combinations of models' characteristics.
\end{abstract}

Keywords: Breeding. Modeling. Production system. Reproduction.

\section{RESUMO}

O método de reprodução mais utilizado em bovinos de corte no Brasil é a monta natural, que corresponde a 84\% dos bezerros nascidos. Os criadores adotam a relação touro:vaca de 1:25, o que resulta em uma subutilização de touros, tornando a reprodução natural antieconômica e subestimando a capacidade reprodutiva de touros competentes. A proporção touro:vaca é determinada por alguns fatores, como clima e nutrição, mas o principal fator determinante é a fertilidade do touro, estimada de forma mais precisa por meio do exame andrológico. O objetivo deste estudo foi construir um modelo de simulação como auxílio para a escolha da melhor relação touro:vaca de acordo com a combinação dos diversos fatores que determinam essa relação. É um modelo conceitual, empírico, estático e determinista que, por meio do processamento dos dados de entrada, simula a melhor relação touro:vaca. O modelo foi desenvolvido no software Vensim PLE 6.1. e descreve variáveis relacionadas a touros e vacas. Duas equações foram geradas para prever o potencial de acasalamento dos machos. Da mesma forma, de acordo com a condição reprodutiva das fêmeas, foram geradas equações para prever a taxa de ciclicidade delas. A soma dessas equações originou o que determina a relação touro:vaca de acordo com a condição reprodutiva das fêmeas. Esse modelo pode servir como um recurso para apoiar a decisão sobre a melhor relação touro:vaca e pode ser usado com várias combinações de características dos modelos.

Palavras-chave: Acasalamento. Reprodução. Simulação. Sistema de produção. 


\section{Correspondence to:}

José Acélio Silveira da Fontoura Júnior

Universidade Federal do Pampa, Curso de Zootecnia

Rua Vinte e Um de Abril, 80, CEP: 96450-000, Dom Pedrito -

RS, Brazil

e-mail: acelio@unipampa.edu.br

Submitted: November 12, 2019

Approved: July 6, 2020

How to cite: Filipini VT, Isola JVV, Neves AP, Barbosa MR, Wienke BCS, Scherer NP, Fontoura Júnior JAS. Simulation models for bull: cow ratio in beef cattle. Braz J Vet Res Anim Sci. 2020;57(3): e164061. https://doi. org/10.11606/issn.1678-4456.bjvras.2020.164061

\section{Introduction}

In Brazil, natural mating is the most used reproduction system, corresponding to $84 \%$ of calves born (Associação Brasileira de Inseminação Artificial, 2019). Normally, breeders adopt a bull:cow ratio of $1: 25$, which is also used in research activities (Oliveira et al., 2015; Santos et al., 2009). According to Fonseca et al. (2000), this results in the underuse of bulls, which makes natural mating antieconomic, underestimating reproductive ability of competent bulls (Chenowet, 2000). In this breeding system, the bull has an important relevance considering that $90 \%$ of males in beef cattle breeding are not selected and not submitted to breeding soundness examination for libido and service ability tests (Oliveira et al., 2007). Finding bulls with a high libido in the herd allows the reduction of the breeding season period, which concentrates calving season in only two months (Oliveira et al., 2007).

The bull:cow ratio proportion is determined by several factors, such as climate and nutrition, but the most important factor is the fertility of the bull, measured through breeding soundness examination of sires (Gandolfo, 2007). Other factors that affect the bull:cow ratio are age, breed, and body condition score of the sire, size of paddocks, and length of breeding season (Barbosa et al., 2007). Santos et al. (2003) reported that Bos taurus indicus bulls have lower libido than Bos taurus taurus, which can also influence bull:cow ratio.

Since the factors that affect bull:cow ratio are variable, it is difficult to establish an economically efficient bull:cow ratio. The use of simulation models, which are a useful tool to minimize time and costs to develop new research, allows simulation of the bull:cow ratio without the need to test different ratios in separate beef farms (Silveira, 2002).

The aim of this study was to develop a simulation model that could be used as a tool to help in the decision of the best bull:cow ratio for each farm, considering various factors known to affect this proportion.

\section{Materials and Methods}

The model in this study is conceptual, experimental, static, and deterministic, and simulates the best bull:cow ratio through input data processing. The model was developed and processed using Vensim PLE 6.1 software. Aiming for a better understanding, a list of initials was created (Table 1), which will be used in text and in the conceptual model (Figure 1).

This model describes the variables related to bulls and cows. For bulls, breeding potential (BP) is an important trait. BP variables include scrotal perimeter and service ability, which is measured by the number of times the bull attempts to mount cows not in estrus in a closed space for a period of 20-40 min. Bulls with greater service ability have higher libido (Rovira, 1996). Based on the data reported by Bavera (2005), addressing the relation between scrotal perimeter and service ability with the number of cows that a bull can breed by natural service, two equations were generated (1 and 2), one refers to SP and the other to SAT, as follows:

Breeding Potential: (72,289 nl (SP)) - 188,94

Breeding Potential: $\left(5,2381^{\star}\right.$ SAT $\left.+28,19\right)$

For Equation 1, the Naperian logarithm (nl) was used to adjust the curve of breeding potential according to SP. This function is the most adjustable to the empirical answer to this variable, considering that reproductive potential increases with the scrotal perimeter to a maximum value, and then remains constant. For SP, the minimum acceptable value used was $30 \mathrm{~cm}$ for a bull with 24 months of age, and the maximum value of $46 \mathrm{~cm}$ for bulls from any age (Bavera, 2005). These isolate values classify a bull to breed 40 and 80 females, respectively, in a 90 -d breeding season. For SAT, the minimum value used was 2 , to a maximum of 9 mounts, which enables the bull to serve approximately 40 and 75 cows, respectively, according to a scale proposed by Blockey (1978), which goes from 0 to 11 or more mounts. These two traits were considered to have the same importance to determine the

Table 1. Initials used in text and conceptual model

\begin{tabular}{cc}
\hline Initials & Definitions \\
\hline BCS & Body condition score \\
SP & Scrotal perimeter \\
SAT & Service ability test, for Bos taurustaurus breeds \\
RS & Reproductive status (females) \\
DPP & Days post-partum \\
BS & Breeding season \\
BP & Breeding potential \\
\hline
\end{tabular}




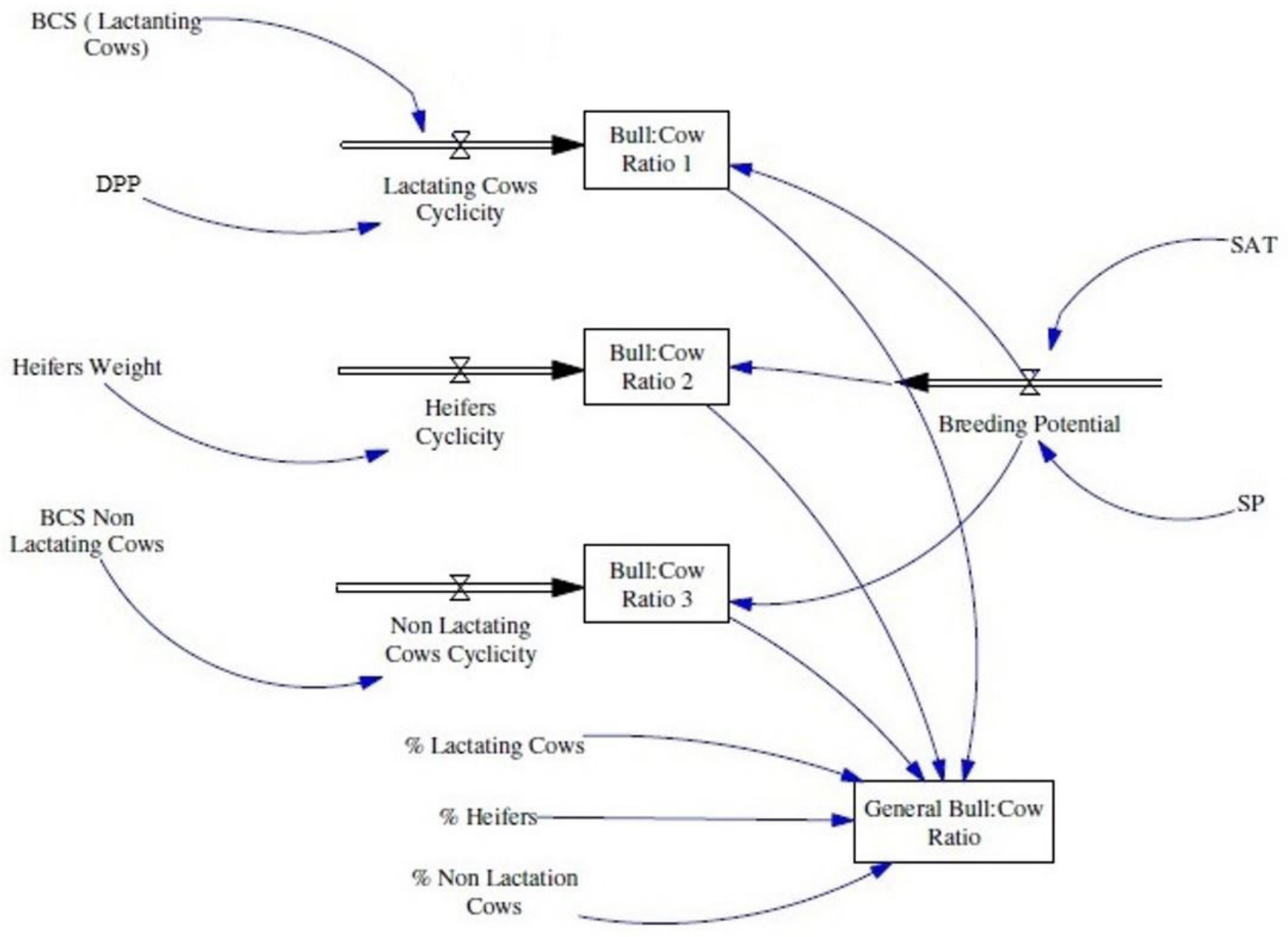

Figure 1. Conceptual model of bull:cow ratio.

Simple blue arrows = indicates to a variable that there is another variable that will be used in an equation; Double black arrows = represents an equation; Boxes $=$ Results of the sum or relative proportion of one or more equations.

breeding potential of bulls. If the bull has a good service ability, but a small scrotal perimeter, this bull may fertilize a lower number of cows, due to its limited SP. In the same way, if the animal has a good SP, but a low service ability, this will be the limiting factor. Therefore, a weight of 0,5 was attributed to each of the traits. Then, Equations 1 and 2 were added to determine this potential, according to Equation 3:

Breeding Potential: $(72,289 \mathrm{nl}(\mathrm{SP})-188,94)^{\star} 0,5+\left(5,2381^{\star} \mathrm{SAT}\right.$ $+28,19)^{\star} 0,5$

For cows, ovarian cyclicity was considered for the analyses. For lactating cows, DPP and BCS at the beginning of breeding season were variables considered to estimate cyclicity. For heifers (minimum 12 months of age), body weight at the beginning of season was considered (Equation 7), and for nonlactating cows, only BCS (Equation 8). To generate equations, data according to Valle et al. (1998) were used, which relates different intervals of DPP and BCS with estrus occurrence. Thus, two equations were generated, one for BCS (Equation 4) and another for DPP (Equation 5):
Cyclicity: $1,875^{\star} \mathrm{BCS}^{2}+44,125$

Cyclicity: 98,98*nl (DPP) - 343,53

For Equation 5, nl was used to adjust the cyclicity curve according to DPP, due to this function being the most adequate to the empirical answer expected, considering that the cyclicity rate of beef cows increases to levels close to $100 \%$ as DPP increases.

For BCS analyses, a 1-5 scale was used, with 1 being extremely thin and 5 extremely fat (Moraes et al., 2005). For DPP, a minimum of $45 \mathrm{~d}$ and a maximum of $200 \mathrm{~d}$ were used, varying, in the simulation, within this scope. If at parturition, the cow has an adequate BCS, around 3.0, without losing body weight during post-partum period, it may probably anticipate estrus occurrence, decreasing DPP. However, if this cow has low BCS at calving, it may prolong DPP until estrus occurrence. Thus, a greater importance was attributed to BCS in the equation that determines cows cyclicity, attributing a weight of 0,7 for this trait, according to Equation 6: 
Cyclicity of lactating cows: $\left(1,875^{\star} \mathrm{BCS}^{2}+44,125\right)^{\star} 0,7+$ $\left(98,98^{\star} \mathrm{nl}(\mathrm{DPP})-343,53^{\star} 0,3\right.$

Cyclicity heifers: $\left(222,55^{\star} \mathrm{nl}\right.$ (Weight)) -1200,9

Cyclicity nonlactating cows: $\left(-2,25^{\star} \mathrm{BCS}^{2}+22^{\star} \mathrm{BCS}+46,25\right)$

According to the described to SP, nl was used, due to the fact that, as the heifer increased body weight in the beginning of the breeding season, conception odds also increased, to a limit where the body weight increase is not able to promote any further increase in conception risk (Barcellos et al., 2006).

To generate only one equation to simulate bull:cow ratio, we considered that cycling cows has a greater influence than breeding potential of bulls in determining this ratio, so that a higher relative weight was given to this trait. Finally, two variables were summed up: cows cyclicity and breeding potential of bulls, to generate Equation 9, which results in bull:cow ratio:

Bull:Cow ratio: (Breeding Potential $\left.{ }^{\star} 0.4\right)+\left(\right.$ Cyclicity $\left.^{\star} 0.6\right)$

This equation was used to determine different ratios, to lactating cows, heifers and nonlactating cows. Besides, a general bull:cow ratio was generated, considering the former 3 ratios and percentage of each cow category, thus generating Equation 10:

General BCR: $\left(\left(\right.\right.$ BCR $1^{\star}(\%$ Lactating cows $\left./ 100)\right)+($ BCR $2^{\star}(\%$ Heifers $\left./ 100)\right)+\left(\right.$ BCR $3^{*}(\%$ Nonlactating cows/100) $\left.)\right)$

\section{Results and Discussion}

The model created in the present study has phonotypical, physiological and structural traits of beef herds, which are considered particularly important to determine bull:cow ratio. An example is SP, which, according to Galvani et al. (2000), is an easily measurable reproductive parameter that has been used as an indicator of sperm output to select young bulls. This trait has high to moderate heritability and negative correlation with age at puberty onset of female offspring (Galvani et al., 2000),

The breed of the bull is also an important factor to be considered, since Bos taurus indicus bulls have lower libido than Bos taurus taurus bulls (Santos et al., 2003). Thus, different tests are performed to assess breeding soundness of these animals. Pineda et al. (2000) suggest for Bos taurus indicus bulls the addition of the libido test to the breeding soundness to select a sire with better reproductive performance. For Bos taurus taurus bulls,
Acuña et al. (2003) recommend the service ability test. Bulls with higher service ability tend to increase the pregnancy rate of the cows more than those with a smaller service ability. Also, Quirino et al. (2004) report that service capacity was considered useful in assessing the fertility of the bull. Their results suggested that direct selection for libido would lead to a desirable correlated response in the body weight, physical and morphological characteristics of the sperm, and an undesirable correlated response to scrotal circumference.

The age of the bull is another important variable. Bulls may be introduced in the reproductive management of beef farms with 14-15 months of age, but in a moderate basis, because they wear out quickly due to young age and lack of sexual experience (Bavera, 2005). This trait was not considered in the model due to lack of information relative to age influence on bull:cow ratio and also due to the fact that most beef farmers usually prefer older bulls instead of young bulls.

Bulls must have an adequate BCS at the beginning of breeding season (Stahringer, 2003), with the aim to have enough body fat reserves, allowing them to have a moderate body weight loss during breeding season. Bulls used in beef herds must not be obese, because this may affect body thermoregulation and, consequently, testicular thermoregulation, hormonal balance, and epididymal sperm reserve (Santos et al., 2005). However, BCS must not also be too low, since it can impair the performance of the bull due to low testicular and body weight, reflecting in lower fertility rates. According to Stahringer (2003), bulls must initiate service with a BCS between 5 and 6 (1-9 scale), allowing them to lose from 1 to $1.5 \mathrm{BCS}$ without a negative effect on their reproductive performance. This trait was not considered in the model due to lack of information on how this variable affects bull:cow ratio.

Among cow characteristics, the model considered BCS at the beginning of the breeding season. BCS is an evaluation of the amount of body fat reserves of the animals, defined by scores. Thus, BCS at the onset of breeding season and its variation during this period will certainly affect the pregnancy rate of cows at the end of the breeding season. Cows with higher BCS probably show higher pregnancy rates than cows with lower BCS (Spitzer et al., 1995; Lake et al., 2005). The BCS of the cow at calving reflects the duration of postpartum anestrous. Orcasberro (1994) reported that cows with BCS 2 ( 1 to 9 scale), at this stage, have a postpartum anestrous longer than three months, with a BCS 3 a 80-d anestrus, whereas a BCS 4 anestrous reduced to 35 to $50 \mathrm{~d}$. In this sense, Fontoura Júnior et al. 
(2009) reported in their simulation model that BCS at calving is a determinant factor of calving-conception interval of the cows.

The reproductive status of lactating cows, heifers or non-lactating cows has a cyclicity rate for each category. Assis et al. (2000) showed that 82.2\% of Aberdeen Angus heifers presented estrus prior to $42 \mathrm{~d}$ of breeding season. Quadro \& Lobato (2006) found a cyclicity rate of $6.81 \%$ for lactating primiparous ( $1 / 2$ Hereford $\mathrm{x} 1 / 4$ Nelore $\mathrm{x} 1 / 4$ Charolais) cows with an average age of 3 years. Pfeifer et al. (2007), studying the pregnancy rate and conception period in different categories of beef cattle, verified similarity in heifers and nonlactating cows. The conception rate of these categories was higher than that of lactating cows, and the conception was earlier.

Another important characteristic when dealing with lactating cows refers to the days postpartum (DPP). The higher the DPP, the longer the recovery time will be for the cow. On the other hand, the chances of the cow becoming pregnant during the period of breeding season will be reduced. In order to obtain one calf a year, the calving-conception interval of the cow should not be longer than $85 \mathrm{~d}$ (Orcasberro, 1994). In healthy cows with an adequate nutritional management, the first estrus behavior after calving must happen between 4550 DPP (Rovira, 1996).

Regarding breeding season duration, Oliveira et al. (2006) recommended a 60- to 90 -d season for adult cows. For heifers, this period should not exceed $45 \mathrm{~d}$, and both the beginning and the end of the season must be anticipated at least $30 \mathrm{~d}$ in relation to the adult cows (Marques et al., 2005). Rovira (1996) also recommends that this season be no longer than $82 \mathrm{~d}$ in order to ensure that all cows have calved before the onset of the next breeding season.

The relief and topography of the paddocks should be considered to determine the number of females that a bull can breed maintaining satisfactory fertility indexes. However, it is not known how the performance of a bull can be influenced by paddock size and relief. Boyd (1991), working for 10 years on mountainous terrain in the Colorado region of the USA, with bull:cow ratios of 1:16 and 1:26, found a $90 \%$ pregnancy rate for both ratios. Although working with a low bull:cow ratio (1:16), the author verified that the relief factor did not influence the reproductive performance of the bulls. These characteristics are not considered in the model due to the factors already mentioned, such as the low amount of information, mainly quantifications.

The output data are generated from the information provided by the user, and a general bull:cow ratio as well as one for each category of cows according to their reproductive condition are determined. In this way, the model can be used in cases where the beef farms have specific breeding paddocks. It is possible to establish the bull:cow ratio for a given herd and a certain category of females kept in that area.

In view of the difficulties faced by the farmer in establishing an appropriate bull:cow ratio, the model simulates the best relation, based on the model input data, without the risk of a low pregnancy rate and excessive breeding use.

The interaction of factors considered in this model defines the best relation bull:cow, economically, through the non-excessive use of the bulls, and biologically, with an adequate pregnancy rate, even with the reduction in the number of bulls used. Working with different bull:cow ratio, in lowlands, Sereno et al. (2002), concluded that it is possible to reduce the bull:cow ratio without negatively influencing herd fertility rate, and therefore have good economic results, once different factors are considered.

The model, once tested and validated, will serve as a tool to support the decision of the best bull:cow ratio, with the possibility of using it with several combinations of the characteristics considered.

Difficulties were found in creating the formulas and in the variable relations for implantation of the model, since several factors affect the relation bull:cow ratio, but few, and, in some cases, no studies quantify the relation between some factors and their influence in determining the bull:cow ratio. Therefore, more studies should be carried out to investigate the relationships between the characteristics that influence the bull:cow ratio, so that there's a better understanding of and ability to adjust them to different individual production systems.

In this way, work can be done in the future to evaluate, for example, the impact of paddock size and relief, age and BCS of the bulls. There is also little research with European breeds, and further studies are needed to optimize the use of bulls from such breeds.

\section{Conflict of Interest}

The authors state that they have no conflicts of interest to declare.

\section{Ethics Statement}

This experiment did not use animals, since it is a simulation.

\section{Acknowledgements}

To the Academic Development Program from the Federal University of Pampa. 


\section{References}

Acuña CM, Apellaniz A, Canosa MR. Preñez em vacas $\mathrm{y}$ vaquillonas mediante servicio natural com toros para carne de baja y alta capacidade de servicio. Vet Argent. 2003;2020(197):1-7.

Assis RR, Pimentel MA, Jardim POC, Osório JCS, Machado JPM. Influência da bioestimulação com machos vasectomizados na eficiência reprodutiva de novilhas Aberdeen Angus. Revista Brasileira de Agrociencia. 2000;6(3):226-31.

ASBIA: Associação Brasileira de Inseminação Artificial [Internet]. Index Asbia 2019. Uberaba: Asbia; 2019 [cited 2020 Jun 4]. Available from: http://www.asbia.org.br/wpcontent/uploads/2020/02/Index-asbia-1.pdf.

Barbosa RT, Machado R, Bergamaschi MACM. Como calcular a proporção touro:vaca para a estação de monta de bovinos de corte. São Carlos: Embrapa Pecuária Sudeste; 2007. 10 p. (Embrapa Pecuária Sudeste. Circular Técnica; 53).

Barcellos JOJ, Silva MD, Prates ER, Costa EC. Taxas de Prenhez em novilhas de corte acasaladas aos 18 e 24 meses de idade. Arq Bras Med Vet Zootec. 2006;58(6):1168-73. http://dx.doi.org/10.1590/S0102-09352006000600028.

Bavera GA. Edad de utilizacion de los toros. Curso de producción Bovina de Carne, FAV UNRC; 2005. [Internet]. Argentina: Site of Produccion Animal. [cited 19 Mar 2019]. Available from: www.produccion-animal.com.ar.

Blockey MA. The influence of serving capacity of bulls on herd fertility. J Anim Sci. 1978;46(3):589-95. http://dx.doi. org/10.2527/jas1978.463589x.

Boyd GW. Exploring mating loads for modern beef bulls. In: Proceedings of the 12th Range Beef Cow Symposium; 1991 Dec 3-5; Fort Collins, Colorado. Lincoln: University of Nebraska; 1991. https://doi.org/10.2527/jas1978.463589x.

Chenowet PJ. Topics in Bull Fertility. Ithaca NY: International Veterinary Information Service; 2000. Bull Sex Drive and Reproductive Behavior. [cited 2020 July 6]. Available from: www.ivis.org.

Fonseca VO, Freando CS, Bergmann JAG. Potencial reprodutivo e econômico de touros Nelore acasalados coletivamente na proporção de um touro para 80 vacas. Arq. Bras. Med. Vet. Zootec. 2000;52(1):1156-61. https:// doi.org/10.1590/S0102-09352000000100017.
Fontoura JAS Jr, Siewerdt F, Dionello NJL, Corrêa MN. Modelo de simulação do desempenho reprodutivo de fêmeas bovinas de corte com base no escore de condição corporal. Rev Bras Zootec. 2009;38(8):1627-35. http:// dx.doi.org/10.1590/S1516-35982009000800030.

Galvani F, Costa EP, Torres CAA, Bruschi JH, Santos MD, Pinheiro RW. Perímetro escrotal, características físicas do sêmen e morfológicas dos espermatozóides de touros Nelore de alta libido comparados com animais de libido inferior. Ars Vet. 2000;16(2):97-103.

Gandolfo EF. Avaliação reprodutiva em touro [monografia]. São José do Rio Preto: Universidade Castelo Branco, Faculdade de Medicina Veterinária; 2007.67 p.

Lake SL, Scholljegerdes EJ, Atkinson RLV, Nayigihugu SI, Paisley DC, Rule GE, Moss TJ, Robinson BW, Hess BW. Body condition score at parturition and postpartum supplemental fat effects on cow and calf performance. J Anim Sci. 2005;83(12):2908-17. http://dx.doi.org/10.2527/2005.83122908x. PMid:16282631.

Marques EG, Santos KJG, Faria WN. Implantação de estação de monta em rebanhos de corte. Revista Eletrônica Faculdade Montes Belos. 2005;1(1):13-21.

Moraes JCF, Jaume CM, Souza CJH. Controle da reprodução em bovinos de corte. Bagé: Embrapa Pecuária Sul (Comunicado técnico; 58). 2005.

Oliveira CB, Guimarães JD, Costa EP, Siqueira JB, Torres CAA, Carvalho GR, Guimarães SEF. Avaliação do comportamento sexual em touros Nelore: comparação entre os testes da libido em curral e do comportamento sexual a campo. Rev Bras Zootec. 2007;36(1):32-42. http://dx.doi.org/10.1590/ S1516-35982007000100005.

Oliveira NM, Rezende MPG, Abreu UGP, Rosa NA, Sterza FAM, Fialho ALL. Environmental effects on reproductive performance of Nellore cows widely raised in the Cerrado/ Pantanal ecotone. Acta Scientiarum Animal Science, Maringá. 2015;37(1):77-82. http://dx.doi.org/10.4025/ actascianimsci.v37i1.24391.

Oliveira RL, Barbosa MAAF, Ladeira MM, Silva MMP, Ziviani AC, Bagaldo AR. Nutrição e manejo de bovinos de corte na fase de cria. Rev Bras Saúde Prod Anim. 2006;7(1):57-86.

Orcasberro R. Estado corporal, control del amamantamiento y performance reproductiva de rodeos de cria. In: Carámbula 
M, Vaz Martins D, Indarte E. editors. Pasturas y producción animal en areas de ganadería extensiva. Montevideo, Uruguay: INIA; 1994. p. 158-69. (Serie Técnica; 13).

Pfeifer LFM, Varela AS, Fontoura Júnior JAS, Schneider A, Correa MN, Dionello NJL. Efeito da condição corporal avaliada no diagnóstico de gestação sobre o momento da concepção e taxa de prenhez em vacas de corte. Acta Scientiae Veterinariae, Porto Alegre. 2007;35(3):303-7. http://dx.doi.org/10.22456/1679-9216.16120.

Pineda NR, Fonseca VO, Albuquerque LG. Estudo preliminar da influência do perímetro escrotal sobre a libido em touros jovens da raça Nelore. Arq. Bras. Med. Vet. Zootec. 2000;52(1):69-75. https://doi.org/10.1590/ S0102-09352000000100016.

Quadro SAF, Lobato JFP. Bioestimulação e comportamento reprodutivo de vacas de corte. Acta Scientiarum Animal Science, Maringá. 2006;28(4):401-7. http://dx.doi.org/10.4025/ actascianimsci.v28i4.602.

Quirino GR, Bergmann JAG, Vale Filho VR, Andrade VJ, Reis SR, Mendonça RM, Fonseca GG. Genetic parameters of libido in Brazilian Nellore bulls. Theriogenology. 2004;62(12):1-7. http://dx.doi.org/10.1016/S0093-691X(03)00125-0. PMid:15159096.

Rovira J. Manejo nutritivo de los rodeos de cria en pastoreo. Montevideo, Uruguai: Ed. Hemisfério Sur; 1996. 288p.

Santos KJG, Melo CS, Pales AP. Seleção de touros através da puberdade, maturidade e fatores envolvidos na fertilidade. Revista Eletrônica Faculdade Montes Belos, Goiás. 2005;1(1):72-87.

Santos MD, Torres CAA, Guimarães JD, Ruas JRM, Carvalho GR. Libido de touros Nelore: efeito da proporção touro: vaca sobre a taxa de gestação. Arq. Bras. Med. Vet. Zootec. 2003;55(3). https://doi.org/10.1590/S0102-09352003000300008.

Santos AS, Abreu UGP, Souza GS, Catto JB. Condição corporal, variação de peso e desempenho reprodutivo de vacas de cria em pastagem nativa no Pantanal. Rev Bras Zootec. 2009;38(2):497-503. http://dx.doi.org/10.1590/ S1516-35982009000200019.

Sereno JRB, Silva EVC, Mores CM. Reduction of the Bull: Cow ratio in the Brazilian Pantanal. Pesqui Agropecu Bras. 2002;32(12):1811-7. http://dx.doi.org/10.1590/S0100204X2002001200019.

Silveira VCP. Pampa-Corte - Um Modelo de Simulação para o crescimento e engorda de gado de corte. Ciência Rural, Santa Maria. 2002;32(3):543-52. http://dx.doi.org/10.1590/ S0103-84782002000300029.

Spitzer JC, Morrison DG, Wettemann RP, Faulkne LC. Reproductive responses and calf birth and weanning weights as affected by body condition at parturitation and pospartum weight gain in primiparous cows. J Anim Sci. 1995;73(5):1251-7. http://dx.doi.org/10.2527/1995.7351251x. PMid:7665355.

Stahringer RC. Evaluación y manejo de toros. Chaco, Argentina: Centro Regional Chaco-Formosa, INTA EEA Colonia Benítez; 2003. (Hoja de Divulgación Técnica, 11).

Valle ER, Andreotti R, Thiago LRLS. Estratégias para aumento da eficiência reprodutiva e produtiva em bovinos de corte. Campo Grande: EMBRAPA-CNPGC; 1998. 80p. (Documento; 71).

Financial Support: Scholarship for the academic development program of the Federal University of Pampa. 